\title{
The concept "blue growth" as a way for sustainable development of the fisheries
}

\author{
Nataliya Yarkina $^{1}$ and Nataliya Logunova ${ }^{1, *}$ \\ ${ }^{1}$ Kerch State Maritime Technological University, 298309, 82 Ordzhonikidze St., Kerch, Republic of \\ Crimea, Russia
}

\begin{abstract}
The article considers the concept of sustainable development as a means of ensuring the economic, social and environmental goals of society in their inconsistency and interdependence. The significance and potential of the global fisheries as a subject of solving the sustainable development targets are shown. A conceptual framework of the Blue Growth initiative has been developed.
\end{abstract}

\section{Introduction}

The trinity of the contemporary world (the world of Nature, the world of People, the world of Business) is characterized by an imbalance in the harmonious coexistence of its components with the world of Business obviously pursuing only its own interest at the expense of the others. When integrating, the stated worlds have a multidirectional influence on each other, different in the impact level and consequences. The world of Nature turned out to be the most vulnerable. The world of Business draws resources from it to obtain economic benefit and is unlikely to voluntarily agree to reduce them. However, Man (in fact, a "child" of Nature, a part separated from it) is dependent on Business that provides him with economic and social benefits, which will become increasingly scarce as natural resources and opportunities are depleted. Aware of the upcoming challenges and threats to their prosperous existence, people have created an international organization (the United Nations). The organization has its unique legitimacy, which is the basis of a collective security system that takes the initiative in solving the world economic problems of survival and sustainable development.

The objective of the article is to study the focus and interdependence of programs and initiatives included in the agenda of the UN and its specialized agencies (in particular, FAO). The study is carried out within the framework of the problem of sustainable human development in harmony with the natural environment, as well as the potential of fisheries as a subject of solving the target purposes of sustainable development.

\section{Materials and research methods}

The study is based on policy documents and official reports of the UN and FAO. The achievement of the research objective has been promoted by the use of such scientific

\footnotetext{
*Corresponding author: natalya_logunova@mail.ru
} 
approaches and methods as the dialectical approach, which is a method of learning about reality, its contradictory nature, integrity and development, as well as logic techniques, including analysis and synthesis, which predetermine the possibility of considering the studied object (sustainable development as a paradigm of the modern world) as a whole.

Results. Humanity is in that stage of its development when ignoring the problems of the natural world, provoked and aggravated by Man, will inevitably lead to the collapse of modern civilization. Given climate change, unprecedented in its consequences, environmental and resource degradation, there is no doubt that the threat of large-scale hunger and lack of livelihoods for a large number of the planet's inhabitants will become a reality as early as the middle of the 21 st century.

A unique, comprehensive solution focused on the necessary changes on the way of sustainable and insensitive to external factors development for the benefit of everyone is the program document endorsed at the 2015 United Nations Sustainable Development Summit, called the "The 2030 Agenda for Sustainable Development" [1]. The agenda includes 17 Sustainable Development Goals that officially entered into force on January 01, 2016 (Fig. 1) and 169 targets of technical, institutional and political changes, the comprehensive implementation of which is considered as a key to achieving sustainable development.

Sustainable development is both the goal of modern society and a means of ensuring the vitality and prosperity of its subsequent generations and the planet as a shared home.

Sustainable development is defined as development that meets the needs of people today, without depriving future generations of the opportunity to fulfill their needs [2-3]. And if "development" is clearly perceived as a process of progressive technological, economic, social and other changes aimed at improving the quality of human life, then the word "sustainable" goes beyond the traditional concept of "constant, stable". Based on the content of the established goals, a broad interpretation of the sustainable development may include such definitions as "harmonious", "balanced" and "environmentally sound". Thus, it is consistent with the main idea of the key issue of sustainable development - destruction of resources and degradation of the Earth's ecosystem as a result of anthropogenic impact and ways to solve it.

Moreover, it is characterized by an unsurpassed distribution area (as three quarters of the Earth's surface is water). Thus, fishery:

- is a source (supplier) of raw materials in the field of food production and also ensures food security;

- is a type of economic activity that provides productive employment in the primary production and also contributes to the significant employment creation in the secondary production and in support and service activities, which include cargo transportation, distribution and trade, production of capital goods (fishing vessels, net materials and fishing gear, fish processing equipment, feed, packaging, etc.), research and development, etc. All this provides livelihoods for about 660-820 million people, which is about $10-12 \%$ of the world's total population [4-5]. According to official statistics, 59.5 million people were employed in the primary sector of commercial fisheries and aquaculture (20.5 million in aquaculture and 39.0 million in fisheries) in 2018 [5];

- represented by the leadership of the industry, it is a member of international and regional fisheries organizations, whose activities are aimed at the sustainable use of biological resources of the oceans and solving environmental problems, etc. 


\begin{tabular}{|c|c|}
\hline $\begin{array}{l}\text { Sustainable development } \\
\text { goals }\end{array}$ & Substantive content (main idea) \\
\hline $\begin{array}{l}\text { SDG 1: } \\
\text { Eliminate }\end{array}$ & $\begin{array}{l}\text { Economic growth must be inclusive to ensure } \\
\text { sustainable jobs and equity }\end{array}$ \\
\hline $\begin{array}{l}\text { SDG 2: Erase } \\
\text { hunger and } \\
\text { ensure food }\end{array}$ & $\begin{array}{l}\text { Promoting sustainable agriculture as a sector that offers } \\
\text { key solutions for sustainable development and is central in } \\
\text { the fight against hunger and poverty }\end{array}$ \\
\hline $\begin{array}{l}\text { SDG 3: Establisl } \\
\text { good health and }\end{array}$ & $\begin{array}{l}\text { A key element of sustainable development is to ensure } \\
\text { healthy lives and promote well-being for all at all ages }\end{array}$ \\
\hline $\begin{array}{l}\text { SDG 4: Provide } \\
\text { quality }\end{array}$ & $\begin{array}{l}\text { Quality education based on the principles of accessibility } \\
\text { and equity is the basis for a decent life and sustainable }\end{array}$ \\
\hline $\begin{array}{l}\text { SDG 5: Enforce } \\
\text { gender equality }\end{array}$ & $\begin{array}{l}\text { Gender equality is not only a basic human right, but also a } \\
\text { necessary condition for a peaceful and sustainable }\end{array}$ \\
\hline $\begin{array}{l}\text { SDG 6: Improve } \\
\text { clean water and }\end{array}$ & $\begin{array}{l}\text { Clean and available water resources for all is the key to } \\
\text { sustainable peace }\end{array}$ \\
\hline $\begin{array}{l}\text { SDG 7: Ensure } \\
\text { affordable and }\end{array}$ & Energy is a key contributor to solving today's problems \\
\hline $\begin{array}{l}\text { SDG 8: Create } \\
\text { decent work and } \\
\text { economic }\end{array}$ & $\begin{array}{l}\text { Sustainable economic growth is impossible without } \\
\text { creating conditions for people to have decent work that } \\
\text { ensures economic growth without harm to the environment }\end{array}$ \\
\hline $\begin{array}{l}\text { SDG 9: Increase } \\
\text { industry, } \\
\text { innovation and }\end{array}$ & $\begin{array}{l}\text { Sustainable development is based on the principles of } \\
\text { industrialization and innovation and is impossible without } \\
\text { the availability and steady development of the appropriate }\end{array}$ \\
\hline $\begin{array}{l}\text { SDG 10: } \\
\text { Reduce }\end{array}$ & Reducing inequality within and among countries \\
\hline $\begin{array}{l}\text { SDG 11: } \\
\text { Mobilize } \\
\text { sustainable cit }\end{array}$ & $\begin{array}{l}\text { Ensuring openness, safety, resilience and environmental } \\
\text { sustainability of cities and towns as centers of productive } \\
\text { work and social development }\end{array}$ \\
\hline $\begin{array}{l}\text { SDG 12: } \\
\text { Influence } \\
\text { responsible }\end{array}$ & $\begin{array}{l}\text { Ensuring the transition to rational models of resource } \\
\text { consumption and production of economic benefits based } \\
\text { on the principles of "doing more and better with lower }\end{array}$ \\
\hline $\begin{array}{l}\text { SDG 13: } \\
\text { Combat climate }\end{array}$ & $\begin{array}{l}\text { Climate change knows no bounds and requires a global } \\
\text { solution }\end{array}$ \\
\hline $\begin{array}{l}\text { SDG 14: } \\
\text { Develop life }\end{array}$ & $\begin{array}{l}\text { Conservation and sustainable use of the oceans, seas and } \\
\text { marine resources is a key to sustainable development }\end{array}$ \\
\hline $\begin{array}{l}\text { SDG 15: } \\
\text { Advance life on }\end{array}$ & $\begin{array}{l}\text { Protecting and restoring terrestrial ecosystems and } \\
\text { promoting sustainable use will help to achieve sustainable }\end{array}$ \\
\hline $\begin{array}{l}\text { SDG 16: } \\
\text { Guarantee } \\
\text { peace, justice }\end{array}$ & $\begin{array}{l}\text { Promote peaceful and inclusive societies for sustainable } \\
\text { development, ensure access to justice for all and build } \\
\text { effective institutions at all levels }\end{array}$ \\
\hline $\begin{array}{l}\text { SDG 17: Build } \\
\text { partnership for } \\
\text { sustainable }\end{array}$ & $\begin{array}{l}\text { Sustainable development is impossible without building } \\
\text { partnerships between governments, the private sector and } \\
\text { civil society at the global, regional and local levels }\end{array}$ \\
\hline
\end{tabular}

Fig. 1. Sustainable Development Goals (SDGs) [2].

The General Framework for Sustainable Food and Agriculture, including fisheries and aquaculture [4-5], is also consistent with the 2030 Agenda for Sustainable Development. It 
provides a basis for discussion and promotion of the most effective and concerted action to implement the 2030 Agenda in aquaculture and all other agricultural sectors.

It is fishery and aquaculture that can make a significant contribution in the implementation of the SDGs. This is due to the specifics of the fishery and aquaculture resource base, which has both a self-reproducing function and the ability to cultivate aquatic biological resources by agricultural methods.

Furthermore, fisheries are among the sectors that have the greatest impact on how land, water, biological and genetic resources, as well as biodiversity are used, thereby determining environmental risks and predetermining the relevant SDGs.

The General Concept for Sustainable Food and Agriculture notes that in order to feed the growing population, agriculture, including fisheries sectors, should not only adapt to the climate change impacts, but also strengthen the resilience of food production systems. This document reveals that "the introduction of sustainable production of crops, livestock products, forestry, fisheries and aquaculture is crucial for achieving many of the SDGs" [4]. Sustainable production of fisheries and aquaculture products, including fish, crustaceans, mollusks and other aquatic animals, as well as algae, etc., will have a direct impact on the successful achievement of SDG 1, SDG 2, SDG 3, SDG 8, SDG 12, SDG 13 , SDG 14 and SDG 15. The importance of fisheries in the implementation of other sustainable development goals should not be underestimated.

Depending on the prevailing circumstances and priorities, the relevance of different SDGs at a particular point in time will vary. Table 1 shows the approximate relevance of certain types of SDGs for the development of fisheries in current time period [7].

Table 1. Classification of the Sustainable Development Goals by level of relevance for the development of fisheries.

\begin{tabular}{|l|l|}
\hline SDGs importance & SDG number in the sustainable development target system \\
\hline High & SDG 2, SDG 8, SDG 12, SDG 14 \\
\hline Secondary & SDG 1, SDG 5, SDG 6, SDG 9, SDG 13, SDG 15, SDG 17 \\
\hline Low & SDG 3, SDG 4, SDG 7, SDG 10, SDG 11, SDG 16 \\
\hline
\end{tabular}

Since in 2018 the number of undernourished people was 820 million or $11 \%$ of the total population, it is clear that the goal on eliminating hunger, ensuring food security and improving nutrition (SDG 1) remains one of the most important ones. It is also obvious that the potential of fisheries is equally critical for solving the problem. Table 2 demonstrates mainly the sharp growth in the production of world fish products in wet weight equivalent compared to the growth in the world's population from the beginning of the last century up to 2018 inclusive.

Under the conditions of stabilization of the volume of fishery production (catch) over the past decades [5], the rapid growth has been seen in aquaculture. However, the increase in this volume is limited, first of all, due to the natural reproductive capacity of the biological resources of the oceans. Moreover, the level of exploitation of the majority of commercial objects has reached a critical level, exceeding which threatens the degradation of the world fishery raw materials. 
Table 2. Dynamics of world catch and the Earth's population for 1900-2018 (according to the data from the following sources $[5,6,8,9])$.

\begin{tabular}{|c|c|c|c|c|c|c|c|c|c|c|c|c|}
\hline Year & 1900 & 1950 & 1960 & 1970 & 1980 & 1990 & 2000 & 2010 & 2015 & 2016 & 2017 & 2018 \\
\hline $\begin{array}{l}\text { World catch, } \\
\text { million tons }\end{array}$ & 4.0 & 21.1 & 40.0 & 70.8 & \begin{tabular}{|l|l|}
71.9 \\
\end{tabular} & \begin{tabular}{|l|l}
97.7 \\
\end{tabular} & 126.0 & 148.1 & \begin{tabular}{|l|l}
168.7 \\
\end{tabular} & $\mid \begin{array}{l}170.9 \\
\end{array}$ & 175.1 & 178.5 \\
\hline $\begin{array}{l}\text { Population of } \\
\text { the Earth, } \\
\text { billion people }\end{array}$ & 1.6 & 2.5 & 3.0 & 3.6 & 4.4 & 5.3 & 6.1 & 6.9 & 7.3 & 7.4 & 7.5 & 7.6 \\
\hline $\begin{array}{l}\text { Average annual } \\
\text { growth rate for } \\
\text { the previous } \\
\text { chain period,\% } \\
\text { - world catch } \\
\text { - population }\end{array}$ & $\begin{array}{l}- \\
-\end{array}$ & $\begin{array}{l}3.4 \\
0.9\end{array}$ & $\begin{array}{l}6.6 \\
1.8\end{array}$ & $\begin{array}{l}5.9 \\
2.2\end{array}$ & $\begin{array}{l}0.2 \\
2.0\end{array}$ & $\begin{array}{l}3.1 \\
1.9\end{array}$ & $\begin{array}{l}2.6 \\
1.4\end{array}$ & $\begin{array}{l}1.6 \\
1.2\end{array}$ & $\begin{array}{l}2.6 \\
1.1\end{array}$ & $\begin{array}{l}1.3 \\
1.4\end{array}$ & $\begin{array}{l}2.5 \\
1.3\end{array}$ & $\begin{array}{l}1.9 \\
1.3\end{array}$ \\
\hline
\end{tabular}

\section{The Sustainable Development Goals}

Thus, if in 1950 (the year of the beginning of official FAO statistics) the share of aquaculture production in the total catch was just over three percent, then in 2018 its level reached $46.0 \%$ (according to [5]), i.e. almost half of the total world fisheries production. At the same time, total world catch increased more than eightfold during this period. Aquaculture also demonstrates a strong potential for promoting sustainable economic growth (SDG 8). With the 2018 ratio of the world catch volume of fisheries and aquaculture in physical terms (in tones) 1.17: 1 (54.0\% and 46.0\%, respectively), the ratio of the market value of fishery and aquaculture products (in initial sale prices) was $0.6: 1$ (37.7\% and $62.3 \%$, respectively) (according to [5]).

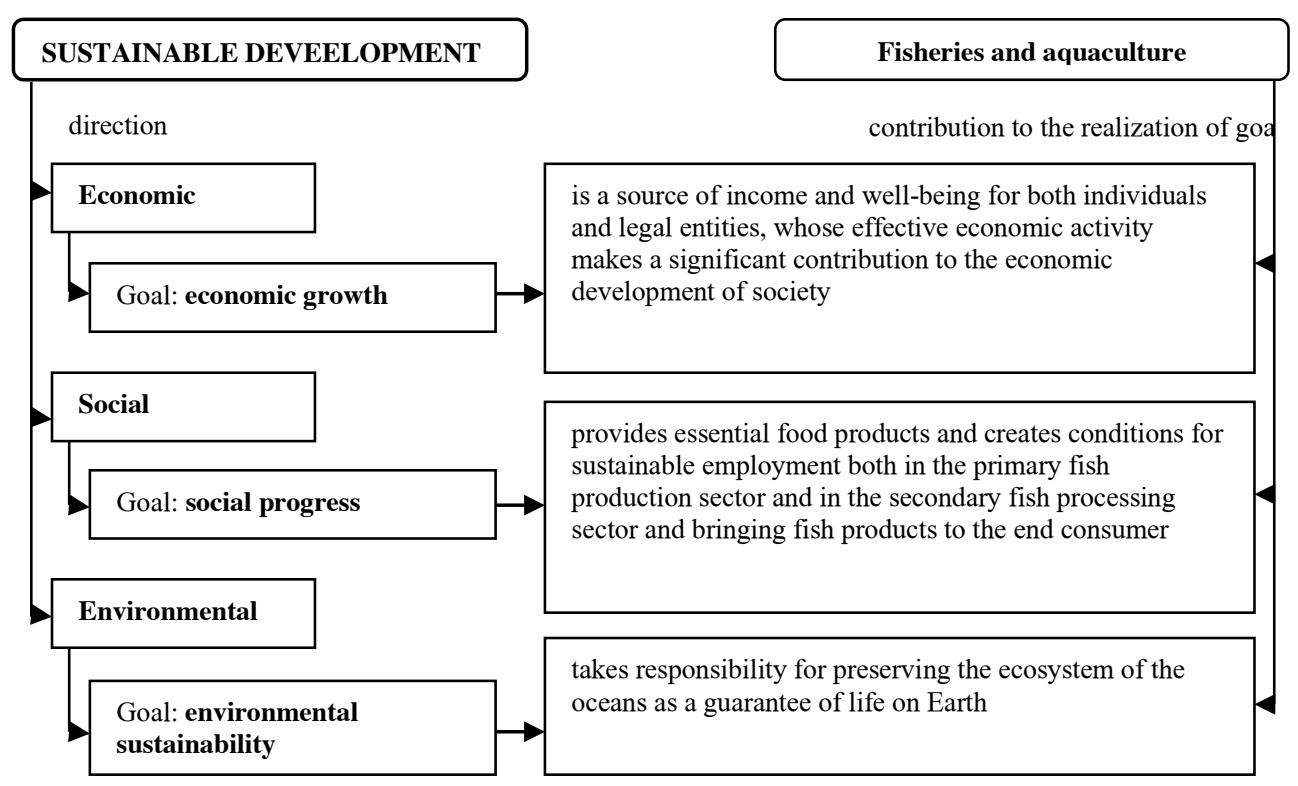

Fig. 2. Components (directions) of sustainable development: fisheries aspect.

Given the global trends in the increase in fish consumption, the growth of meat consumption of all land animals is reduced. The average per capita fish consumption by the world's population increased in 2018 to $20.5 \mathrm{~kg}$. Such level of consumption has been 
achieved not only thanks to an increase in fish catch, but also to other factors, including a reduction in losses and waste, i.e. sustainable use of natural resources (SDG 12).

Despite the clear potential for achieving the Sustainable Development Goals, the world fisheries industry faces global challenges raised by the need to reduce the proportion of fish stocks exploited beyond the bio-sustainability level, which currently is about $33 \%$ of their total mass. The challenges are also related to the biosafety of raw material base, diseases of representatives of marine fauna and other factors, which are based on the violation of the ecosystem of the oceans.

Modern environmental problems threaten the solution of economic and social problems of sustainable development (Fig. 2). This has prompted FAO to launch the Blue Growth Initiative, an innovative, integrated, cross-sectoral approach to water resources management that aims to maximize the environmental benefits and services of the oceans and inland waters and at the same time providing social and economic benefits [6, 12-15].

The Blue Growth initiative aligns with the need of conservation and sustainable use of the oceans, seas and marine resources for sustainable development (SDG 14). The SDG 14 uniqueness stems from the fact that without its implementation, it is almost impossible to achieve other sustainable development goals.

The concept "Blue Growth" was often identified with the concepts "Blue Economy", "Green Economy in a Blue World", "Blue Economy, New Marine Green Economy" [10], which are inherently static. In particular, the "blue economy" is considered as a set of certain economic sectors, including fishing, aquaculture, shipping, energy, tourism, environmental protection and restoration, etc., as well as related water bodies (oceans, seas, rivers, lakes, other inland waters and wetlands).

Sustainable fisheries development is important and indispensable to achieving the SDGs. Thus, knowing that the "zero growth" or "limited growth" underlying the "blue economy" will not meet the growing demand for fish, resulting not only from the increase in world population, but also from the growth of its prosperity and urbanization, FAO put forward the idea of "blue growth" rather than "blue economy". The organization defines the essence of its initiative as "sustainable growth and development resulting from economic activities that use living renewable oceans, wetlands and coastal resources that minimize environmental degradation, biodiversity loss and unsustainable water use, and maximize economic and social benefits" [10].

Key provisions of the Blue Growth initiative, designated as a result of the review of the sources [6] and [10], are shown in Fig. 3. 


\section{BLUE GROWTH Initiative}

Object targeted by the Initiative

Responsible water management aimed at inclusive growth, which should promote sustainable development in all three directions (economic, social, environmental)

n

Areas of primary focus of the

\section{T.}

fisheries, aquaculture, fish processing, and ecosystem (ecological) services, trade and social protection

Methodological approach to the implementation of th

based on the idea of integrating fisheries with other users and services of aquatic ecosystems and applying an integrated methodological approach

Mission of the initiative

남

restore the productive potential of oceans, seas and inland water bodies

Idea of the

?

create favorable conditions for making the population employed in fishing and aquaculture not only use resources but also conserve and sustain them

The basic principle of the initiative

the ecological services provided by aquatic ecosystems (the air we breathe; the food we eat; the water we drink) are indispensible for human well-being

Initiative implementation mechanism

involves the implementation of a set of measures aimed at:

- creating favorable conditions, including the formation of a regulatory and political framework, the development of technical and intellectual potential, stimulation of investment and business activity;

- transformation, through the implementation of demonstration or pilot projects, allowing to determine the most appropriate measures and accumulate the necessary experience;

- mainstreaming which means improving the necessary policies, practices, incentives and technologies and integrating them into government programs and

Main activities of the initiative

ㄴ

- promotion of best practices based on the implementation of ecosystem approaches to fisheries and aquaculture, on which the Blue Growth initiative is based;

- coverage of all stakeholders involved in the supply chain;

- creating favorable conditions for reducing food losses and food waste. increasing

Expected practical results of the initiative

\section{-}

- improving the efficiency of supply chains related to fish and other seafood and creating more efficient livelihoods (SDG 8);

- improving the state of water bodies and ecosystems (SDG 14) and reducing overfishing (SDG 12);

- creating safe food (SDG 2)

Fig. 3. Conceptual Framework of the Blue Growth Initiative. 


\section{Conclusion}

Thus, FAO's Blue Growth initiative aims to achieve sustainable development goals that are designated to maximize economic and social benefits. Meanwhile, it makes it possible to ensure the sustainability and preservation of the environment in the fisheries and aquaculture sectors through the implementation of ecosystem approaches, which form the basis of the Initiative [11-12]. Features of ecosystem approaches to fisheries and aquaculture with regard to the Russian Federation fisheries within the context of sustainable development concept are the subject of further research and publications.

\section{References}

1. United Nations.Resolution adopted by the General Assembly on 25 September 2015. https://www.un.org/en/development/desa/population/publications/2030_Agenda_ru.pdf (Last accessed 12.01.2021)

2. The goal of sustainable development. https://www.un.org/sustainabledevelopment/ru/sustainable-development-goals/ (Last accessed 12.01.2021)

3. Our common future. https://www.un.org/en/ga/pdf/brundtland.pdf (Last accessed 15.01.2021)

4. FAO. Report of the ninth session of the Sub-Committee on Aquaculture, Rome, 24-27 (2017) http://www.fao.org/cofi/31142-044088accd2527a46cfbe032a61eb59e.pdf (Last accessed 16.01.2021)

5. Fisheries and Aquaculture: Part 1. World review of fisheries and aquaculture, Rome (2012) http://www.fao.org/docrep/016/i2727r/i2727r01.pdf (Last accessed 16.01.2021)

6. FAO. The State of World Fisheries and Aquaculture 2018 - Meeting the sustainable development goals. Licence: CC BY-NC-SA 3.0 IGO. Rome (2018) http://www.fao.org/3/i9540EN/i9540en.pdf (Last accessed 18.01.2021)

7. FAO. Fisheries and Aquaculture Circular No. 1141. The 2030 Agenda and the Sustainable Development Goals: The challenge for aquaculture development and management, Rome (2017) http://www.fao.org/cofi/386630a3e5c407f3fb23a0e1a3a4fa62d7420c.pdf (Last accessed 18.01.2021)

8. World population https://countrymeters.info/ru/World9 (Last accessed 18.01.2021)

9. FAO. Food Outlook - Biannual Report on Global Food Markets. Rome, 104 (2018) http://www.fao.org/3/CA2320EN/ca2320en.pdf (Last accessed 18.01.2021)

10. FAO. The FAO Blue Growth Initiative and aquaculture. Available at: http://www.fao.org/cofi/43732-0d96f652208820299a272b5bd477b0406.pdf

11. N. Yarkina, N. Logunova, Applied potential of econometric instrumentation of substantiation of economic decisions within fisheries sector. Topical Problems of Architecture, Civil Engineering and Environmental Economics (TPACEE 2018): E3S Web Conf. 91, 08054 (2019) https://doi.org/10.1051/e3sconf/20199108054

12. N. N. Yarkina. Sustainable development and the Blue Growth Initiative Bulletin of the Kerch State Marine Technological University, 3, 117-131 (2019)

13. S. Chernyi, V. Budnik, "Methods for optimizing solutions when considering group arguments by team of experts" (2017) https://doi.org/10.1063/1.5009873.

14. S. Chernyi, N. Logunova, L. Aleksahina, Institutional and organizational aspects of regional marine transport system strategic development. International Conference 
"Quality Management,Transport and Information Security, Information Technologies" (IT\&QM\&IS) (2017) https://doi.org/10.1109/itmqis.2017.8085780

15. V. Reshnyak, S. Sokolov, S. Chernyi, T. Storchak, Y. Tihomirov, System aspect course of creation of information and analytical system of environmental monitoring and control, IOP Conference Series: Earth and Environmental Science, 87(4), 042017 (2017) https://doi.org/10.1088/1755-1315/87/4/042017 